\title{
Quantifying channel bank erosion of a small mountain river in Russian wet subtropics using erosion pins
}

\author{
Yulia Kuznetsova $^{1}$, Valentin Golosov ${ }^{1,2,3}$, Anatoly Tsyplenkov ${ }^{1,3}$, and Nadezhda Ivanova ${ }^{1}$ \\ ${ }^{1}$ Laboratory of Soil Erosion and Fluvial Processes, Faculty of Geography, \\ Moscow State University, GSP-1, Leninskie Gory, 119991, Moscow, Russia \\ ${ }^{2}$ Kazan Federal University, Kremlevskaya st., 18, 420008, Kazan, Russia \\ ${ }^{3}$ Institute of Geography RAS, Staromonetny per., 18, 119017, Moscow, Russia \\ Correspondence: Yulia Kuznetsova (kuzyulia@gmail.com)
}

Published: 1 August 2019

\begin{abstract}
Channel bank erosion was monitored using erosion pin arrays in a small mountain stream located in the Tsanyk River basin near the Caucasian Black sea coast. The study area is characterized by high precipitation, low mountainous topography, and flysch bedrock. Erosion pins arrays were installed at six key sections each with different bank lithology and morphology. Bank lithology (bedrock or alluvial deposits), morphology (vertical or concave) and orientation towards the local flow direction were the dominant factors controlling the rate of bank retreat and/or collapse. In contrast to alluvial banks, bedrock slopes are predominantly affected by chemical weathering processes in a wet subtropical climate. Results on sediment mobilization and volume removed are presented for different bank types. Variability in channel bank recessional dynamics is discussed in the context of hydrometeorological data (2016-2018) and an extreme flood.
\end{abstract}

\section{Introduction}

River channel bank erosion is controlled by a complex combination of factors and processes that play a key role in fluvial dynamics (Hooke, 1979). Channel bank retreat involves a combination of three primary mechanisms, which include subaerial weathering, mass failure and fluvial erosion (Thorne, 1982). Other processes such as creep and seepage erosion can be important under certain situations (Lawler, 1993). The wet subtropical area in Russia consists of low relief topography along a narrow strip of the Caucasian Black Sea coast (Fig. 1). This region is extremely popular among tourists because of its climate, topography and proximity to the sea and the region has experienced considerable growth of infrastructure in recent decades. This process has been especially triggered by the recent Winter Olympic Games (Sochi-2014) and a set of Formula-1 races during the following years. Because the spatial extent of marine terraces is limited in this region, infrastructure development is increasingly located on narrow floodplains and steep slopes of valleys that dissect the low mountain belt of the Caucasus Mountains. Mountainous topography and subtropical climatic conditions in combination with easily weathered flysch-dominated bedrock lead to an increased number of geomorphic hazards. According to local authorities, up to $85 \%$ of the slopes in the Sochi administrative area are susceptible to landslides (Shoygu, 2010).

River bank erosion is a second factor that causes damage to buildings typically located next to the channel. Potential hazards of landslides and fluvial erosion may be exacerbated under conditions of a changing climate (Goudie, 2006; Gariano and Guzetti, 2016). Annual precipitation in this area is over $1500 \mathrm{~mm}$ and several heavy rainstorms $(100-200 \mathrm{~mm}$ per event) can occur each year. During the last decade the number of extreme meteorological events have been observed in the Caucasian Black Sea coast region (Meredith et al., 2015; Alekseevsky et al., 2016) and the frequency of high magnitude rain events has been reported (Magritsky, 2014). Accordingly, in order to mitigate risks due to natural hazards in this region it is necessary to investigate key processes that control channel dynamics and bank erosion rates. In the present study, erosion pin arrays were used to quantify the effects of extreme events river bank recessional rates. This 


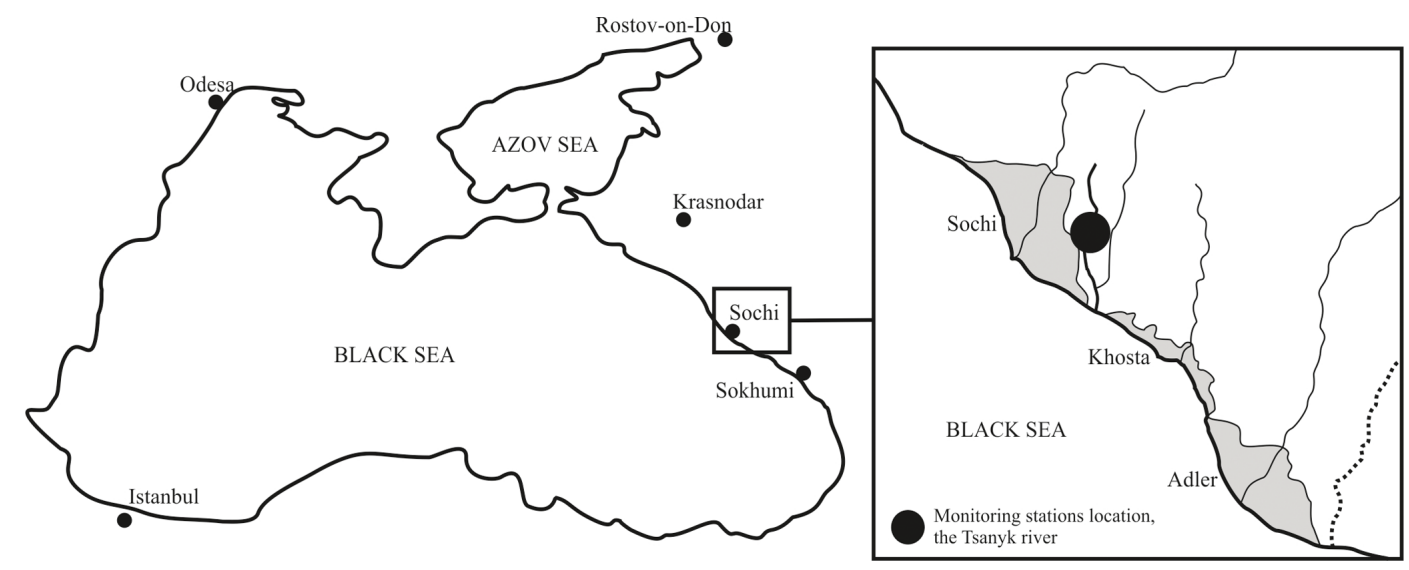

Figure 1. The study site location.

erosion assessment method has been widely applied over the world and advantages and limitations of the method are widely reported (Hooke, 1979; Neller, 1988; Sirvent et al., 1997).

\section{Methodology}

\subsection{Study catchment}

The study was conducted in the Tsanyk river valley which is located in Russia near the coast of the Black Sea (Fig. 1). This area is located in the Big Sochi area in the Khosta district and a monitoring program of exogenic processes has been ongoing since the early 2000s (Kuznetsova et al., 2012; Golosov et al., 2012) and the present study is part of river channel process investigations. The Tsanyk river is $12.5 \mathrm{~km}$ long and drains an area of $11.7 \mathrm{~km}^{2}$. The upper section of the river valley consists of a deep V-shaped gorge underlain by solid bedrock unsuitable for land use. The primary geomorphic hazards in this section of the valley are related to slope instability, mainly rock falls due to fieldwork observations. The stepped long profile of the stream is deeply incised while the lower sections of the valley is predominantly urbanized and has undergone significant landscape change.

Along the middle reach of this river which is $2.3 \mathrm{~km}$ in length, there is a relatively low level of development which is ideal to evaluate erosion in natural channels to estimate sediment redistribution dynamics within the basin. Detailed geomorphic mapping of the entire river reach was performed and the morphological characteristics of more than over 100 channel and valley bottom cross-sections were measured. Information on relative bank height, width, lithology, vegetation type, and dominant exogenic processes was collected. Survey data were used to select representative channel banks with characteristic lithology, slope and soil characteristics (Fig. 2). Notably, two main types of channel banks were evaluated. They include (1) weathered bedrock consisting of flysch and (2) loose loamy alluvial soil with layers of pebbles and other alluvial debris. Fluvial processes such as particle detachment by flowing water are also accompanied by another complex set of other processes that include mass wasting and weathering (Thorne, 1982). Weathering is the process, which constantly affects all types of river banks, but it plays an especially significant role for bedrock banks by preparing the loose material for further removal by a flow.

\subsection{Bank Erosion Estimation}

Based on a geomorphic survey of the studied river reach, six sections were selected for monitoring of channel banks dynamics. All sites are located along eroded non-vegetated banks but differ in terms of lithology, micromorphology, and orientation towards the stream (Fig. 3). The main characteristics of the sections are listed in Table 1.

In September 2016 erosion pins ( $20 \mathrm{~cm}$ long steel nails) were deployed at all monitoring sections. All pins were arranged in vertical rows, mostly in checkerboard order. The average distance between neighboring pins ranged from 40 to $60 \mathrm{~cm}$. This density is used to minimize artificial impacts on slope stability, while allowing coverage of all bedrock and soil layers. The exposed parts of the pins were measured in the field with an accuracy of $0.1 \mathrm{~cm}$.

Further measurements were carried out three times: in September 2017, and twice in September 2018 (on 4 September, and right after one extreme flood on 9 September). These measurements allowed changes to channel bank morphology and volumes of the eroded material to be calculated.

In case the pin was not presented at the site, the reason was determined in the field as either erosion to the full length of the pin, or accumulation on top of the pin. In unclear cases we used photographs taken before pins installation and during the repeated measurements to compare local conditions and slope morphology.

For each monitoring section, the map of erosion pins in plan projection was prepared using the GIS software package MapInfo. Based on repeated measurements, a digital sur- 


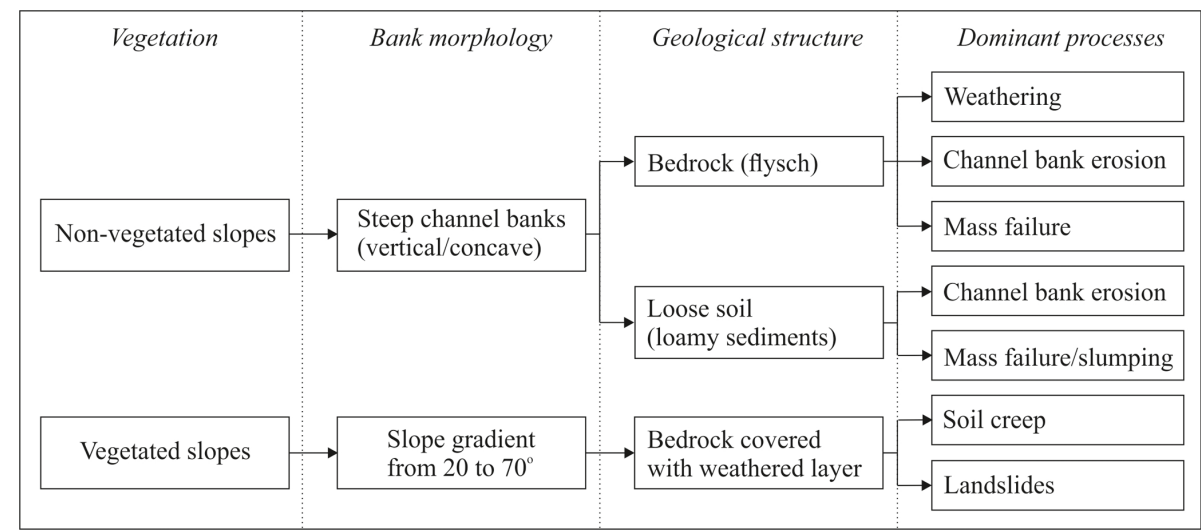

Figure 2. Channel bank types with major characteristics.

Table 1. Monitoring river bank section characteristics.

\begin{tabular}{lrlrl}
\hline Monitoring section & Number of pins & Lithology & Section area $\left(\mathrm{m}^{2}\right)$ & Bank profile morphology \\
\hline 1 & 34 & Loose soil & 6.5 & Vertical slope \\
2 & 10 & Flysch & 1.4 & Concave slope \\
$3 / 1$ & 10 & Flysch & 1.5 & Concave slope \\
$3 / 2$ & 5 & Flysch & 0.2 & Concave slope \\
4 & 16 & Loose soil & 1.5 & Vertical slope \\
5 & 24 & Loose soil & 3.4 & Vertical slope \\
6 & 22 & Loose soil & 2.3 & Vertical slope \\
\hline
\end{tabular}

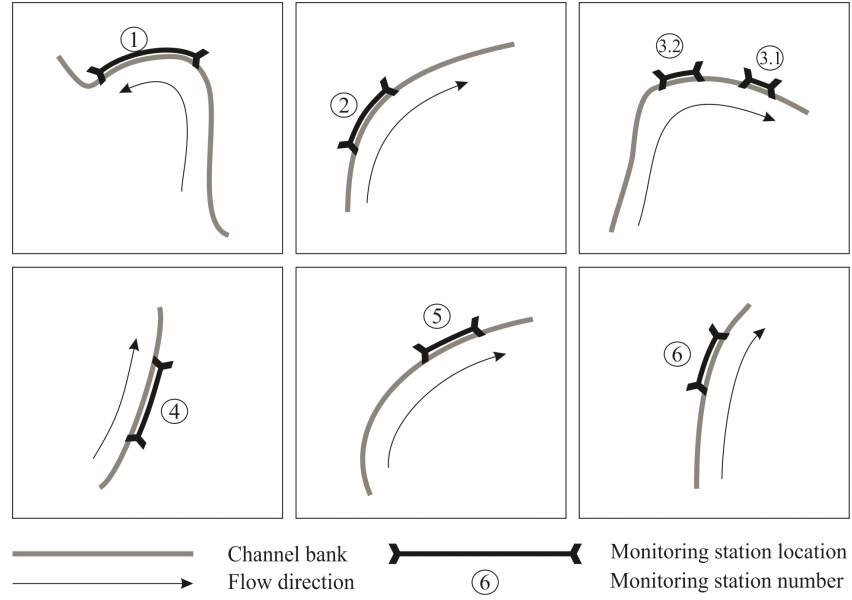

Figure 3. Locations of monitoring sections on the river banks relatively to flow directions.

face model (DSM) and 3-D-model of micro-morphological changes were evaluated for each site and each observation date. The scheme of bank deformation at the monitoring section 6 between 2016 and 2017 is shown in Fig. 4 as an example. Positive values correspond to erosion and negative values correspond to local deposition at the bottom of the eroded bank. In cases where some pins were lost, there were three ways of slope morphology changes calculations. For eroded pins, we used the minimum possible value (its full length of $20 \mathrm{~cm}$ ). When there was deposition on top of the pin we used zero value, which definitely leads to underestimation of sediment redistribution within the particular bank section, but does not affect total erosion rates calculations and helps to keep the sediment in place for further observations. In cases where no reason was established for the missing pin, it was excluded from further calculations. The input of other processes accompanying fluvial erosion (such as mass failure and weathering) is included in calculation results by default.

We used the field measurement of the channel banks height and length of the eroded bank segments for two bank types based on lithology. Sediment volume eroded from the mass movement-dominated slopes are calculated using the soil creep rate and the thickness of the creep-affected weathered layer. For the other channel bank types, we used the average values obtained at the monitoring stations.

\subsection{Hydrometeorological data collection}

Meteorological data were collected at the station, located at Razdolnoe village within the river basin, near the western drainage basin divide of the Tsanyk catchment. Streamflow was measured using automatic level gauge (43.57661, 39.78230) connected to an automatic system of flood monitoring in Krasnodar region (http://www.emercit.ru/map/, last access: 15 September 2018). This system has provided open 


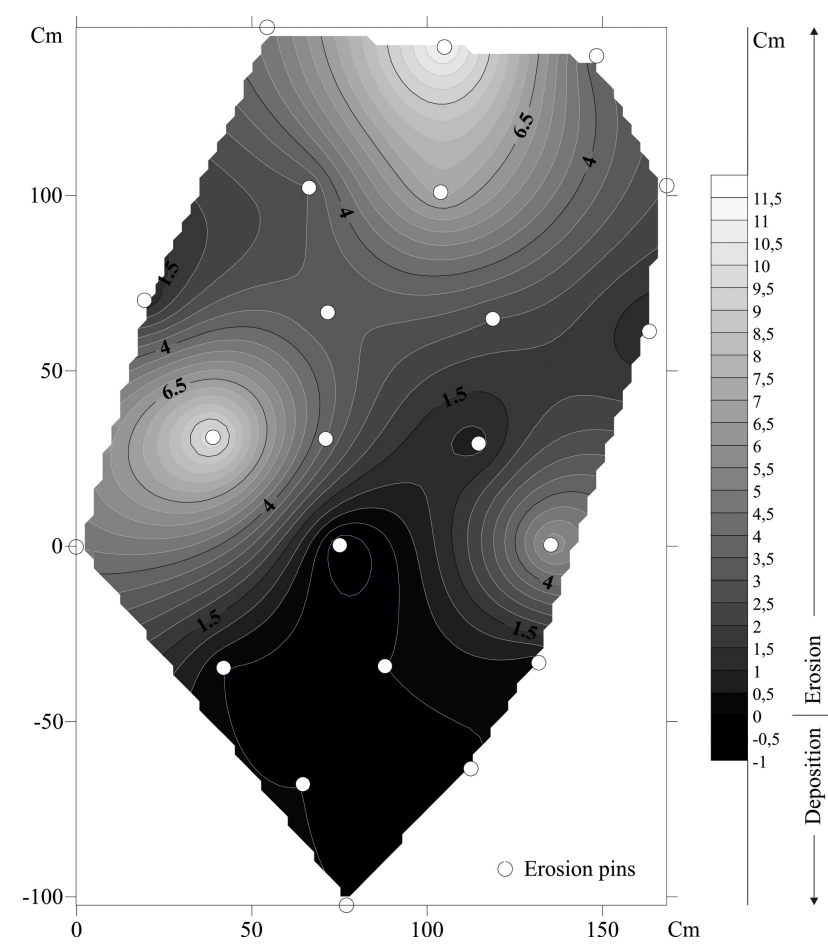

Figure 4. Example map of the channel bank morphology changes. Monitoring section 6, 2016-2017.

source data since 7 April 2014, with 10 min time resolution. Water level assessment accuracy is $1 \mathrm{~mm}$. To avoid artificial peaks and sensor noise the data was corrected manually according to the method of Rodda and Little (2015).

\section{Results and discussion}

The graphs of significant meteorological events and their hydrological responses are shown at Fig. 5. It is clear that most severe rainfall events happen during wet winter season lasting from October till March. Water level fluctuations correspond well to precipitation events.

The two graphs comparison shows some special characteristics of the hydrological response. The same precipitation layer may cause either an extreme flood or almost no water stage rise. Duration of rainfall and the antecedent dry period play the most important role in the response type. In many cases the longer the period of rains, the higher the water level at its end.

Speaking of the two years of observations, there are significant differences in precipitation distribution by seasons and single events. The year 2018 is obviously wetter. It has 1 month longer wet season, with several notable rainfalls in summer, and the autumn rains started early in September with an extreme hydrological and meteorological event (Fig. 6).
Table 2. Mean volumetric bank retreat rates for different monitoring intervals based on application of erosion pin method.

\begin{tabular}{lrrr}
\hline \multirow{2}{*}{$\begin{array}{l}\text { Monitoring } \\
\text { section }\end{array}$} & \multicolumn{3}{c}{ Volume of displaced material $\left(\mathrm{m}^{3} / 10 \mathrm{~m}^{2}\right)$} \\
\cline { 2 - 4 } & $\begin{array}{r}\text { 1 Sep 2016- } \\
\text { 5 Sep 2017 }\end{array}$ & 4 Sep 2017- & 4 Sep 2018- \\
& 0.27 & 0.76 & 9 Sep 2018 \\
\hline 1 & 0.09 & 0.02 & 0.28 \\
2 & 0.24 & 0.50 & 0.27 \\
$3 / 1$ & 0.08 & -0.16 & 0.18 \\
$3 / 2$ & 0.30 & 1.12 & 0.20 \\
4 & 0.42 & -0.14 & - \\
5 & 0.41 & -0.07 & 0.14 \\
6 & & & \\
\hline
\end{tabular}

There was a $43 \mathrm{~mm}$ rainfall layer in the morning of 7 September, and the water level rose up to $36 \mathrm{~cm}$. Additional $23 \mathrm{~mm}$ of rainfall over the next morning caused the $117 \mathrm{~cm}$ water level rise during $40 \mathrm{~min}$ only. Such a high and sharp peak is unique for at least the last 5 years - since the start of water level monitoring at this river. Moreover, it was caused by a regular event $(23 \mathrm{~mm}$ is the $99.9 \%$ frequency rain) that happened approximately $24 \mathrm{~h}$ after $90 \%$ frequency rain $(43 \mathrm{~mm})$. As mentioned above, there is no direct correlation between precipitation rate and water level, and even $25 \%$ or lower recurrence interval rainfall events did not cause such consequences over the last 5 years. We believe that the antecedent dry period duration and certain sequence in rainfall events are the main reasons for this phenomena.

We were lucky in the field to make measurements of erosion pins on all monitoring sections a few days before and immediately after this unique flood event and to assess the input of the extreme event into the channel banks dynamics.

Estimates of bank erosion are presented in Table 2 and Fig. 7. All volumes of displaced material are given in common volumetric denominator $\left(\mathrm{m}^{3}\right.$ of removal or gain over $10 \mathrm{~m}^{2}$ of the channel bank area).

The data show erosion rates both within the single bank section and along the whole river reach, are highly variable depending upon the nature of the bank materials and streamflow. Erosion rates where typically higher in banks composed of loose alluvial material but a number of other factors affecting bank erosion were observed. The bank orientation towards the flow direction plays an important role in the erosion process, which in some cases is even more important than lithology of the eroded banks. The most unstable part of the slope with loose banks is usually located at the meander apex and at bank segments oriented perpendicular to the flow direction.

Bedrock banks are characterized by lower variability of erosion rates than those composed of alluvial sandy-loamy material, apparently more influenced by local factors, such as microscale differences in lithology, morphology, and, mainly, orientation towards the stream flow direction. 

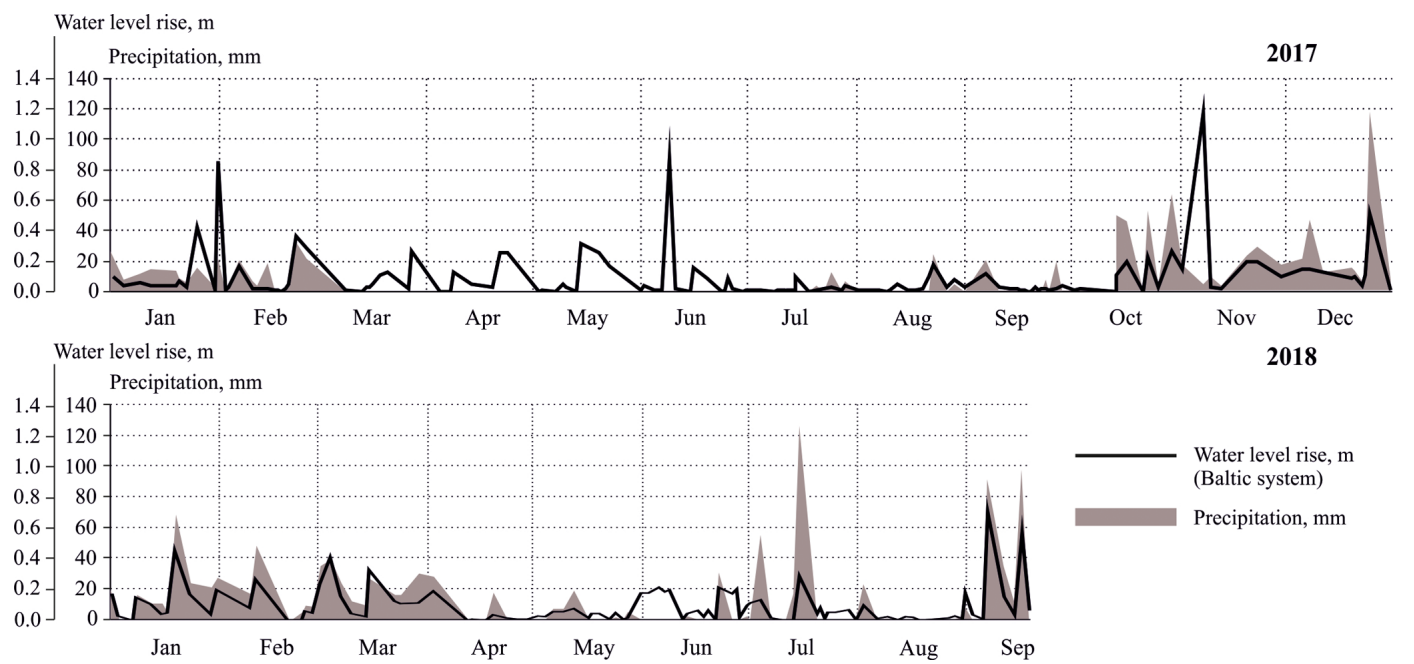

Figure 5. Water level (1) and precipitation (2) changes during the monitoring period.

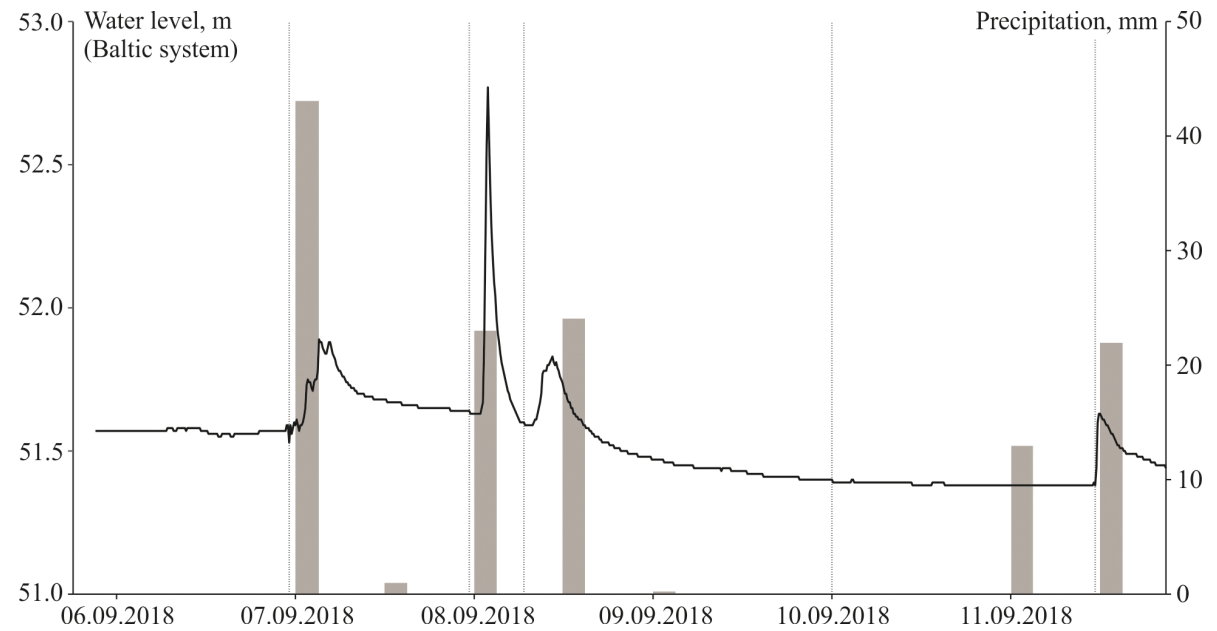

Figure 6. Hydrological events and rainfall in September 2018.

The noticeable exceptions are sections 5 and 6 where the floods of 2018 led to the mass failure of all the channel banks, though the fate of collapsed material depended on the bank orientation towards the channel. The monitored banks at sections 5 and 6 are located in parallel to the stream direction (see Fig. 3), and it takes longer to erode collapsed blocks and flush the produced sediments away. The monitoring results show temporary deposition of the collapsed material along the bank toes at sections 5 and 6 .

At station 3/2 there is an accumulation of talus and small rockfall debris which is located directly where the flow hits the bank (see Fig. 3). We speculate that the main reason for such variability is related to bedrock weathering and the mechanisms of the processes following the erosion events. At this site, erosion of the bottom sections of the banks has triggered the weathered banks to collapse. The lag between bank undercutting and mass failure in such cases can take longer than banks consisting of loose sediments, where slumping and sliding usually immediately follow the undercutting and often occur during the same flood. That is why fluvial erosion at the bedrock banks may be delayed comparatively to the other eroded bank sections. In many cases, failures of bedrock banks occur after one event and the collapsed blocks will be eroded during the next floods.

The comparison of situations observed on the sections 3/1 and $3 / 2$ shows that the bank segment located at the meander exit and parallel to the stream collapses faster than the upstream part of the meander where the flow contacts the bank directly. Flysch at the bank surface has relatively high erosional resistance and the intensity of bank deformation will largely depend on differential weathering rates. The flow has to take away and replace the prepared (weathered) debris. The $3 / 2$ section is located under and overhanging upper part of the high north facing slope, where weathering rates can 


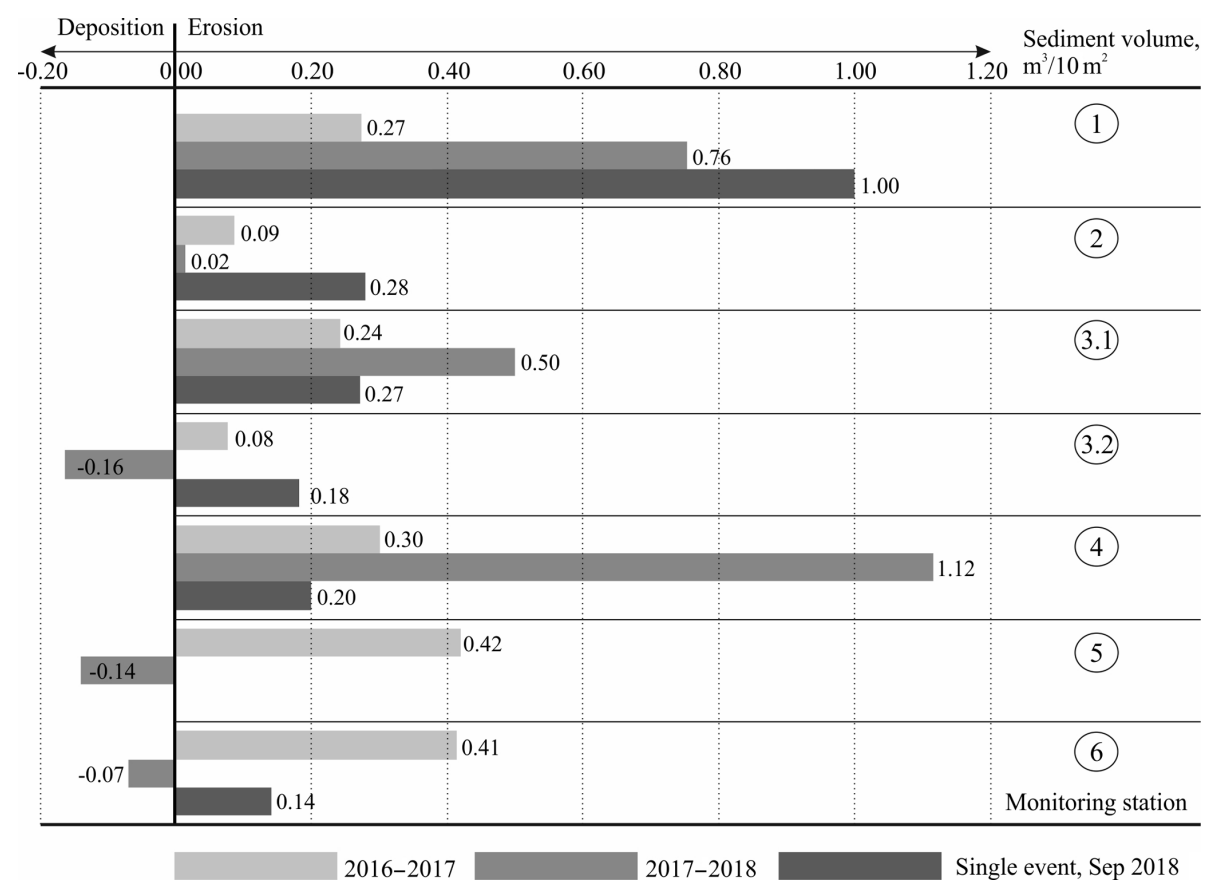

Figure 7. Volumes of mobilized material over the observation periods.

Table 3. Total volumes of displaced material along the studied river reach.

\begin{tabular}{lllrrr}
\hline Channel bank type & Total length of & Average channel & & \multicolumn{2}{c}{ Volume of displaced material, $\mathrm{m}^{3}$} \\
\cline { 4 - 6 } & all segments, $\mathrm{m}$ & $\begin{array}{l}\text { bank relative } \\
\text { height, } \mathrm{m}\end{array}$ & $\begin{array}{r}\text { 1 Sep 2016- } \\
\text { 5 Sep 2017 }\end{array}$ & $\begin{array}{r}\text { 5 Sep 2017- } \\
\text { 4 Sep 2018 }\end{array}$ & $\begin{array}{r}\text { 4 Sep 2018- } \\
\text { 9 Sep 2018 }\end{array}$ \\
\hline Eroded bedrock bank & 550 & 3.5 & 26.2 & 22.8 & 47.3 \\
Eroded loose soil bank & 2050 & 1.8 & 130.4 & 153.7 & 164.7 \\
Vegetated soil creep bank & 800 & - & 1 & 1 & 1 \\
Accumulative bank & 1100 & - & - & - & - \\
\hline
\end{tabular}

be expected to be lower. In contrast, section $3 / 1$ is more susceptible to the temperature fluctuations, so the rocks collapse faster, and the total volume of mobilized debris is greater.

All monitored banks have significant differences in their different parts. The most exposed erosion pins are usually observed at the middle part of the bank, while the lower parts and the toes are often covered with the collapsed sediments, waiting to be flushed away during the following flood event. The only exception observed is the case of the extreme single flood when almost all debris was immediately removed by the stream.

Comparison of results of two years of observation (not accounting for the extreme event) shows that differences of the channel bank dynamics depend on the amount and type of precipitation. Volumes of the displaced material in 2018 are 1.5-2.5 times greater than during the drier previous year of 2017. A number of hydrological events played a significant role in this process. The contribution of the unique hydrological September 2018 event had a dramatic effect on channel bank erosion dynamics. The largest erosion rates occurred in section 1 which consists of loose alluvial sediments oriented towards the flow direction. The volumes of material removed during this particular event was $25 \%$ higher than during the prior 8 months of the wet year, and almost 4 times higher than the total sediment loss over the drier year of 2017 with no significant hydrological events observed. At all other sections, volumes of material displaced over a single extreme event are at least comparable with the annual bank retreat during the previous period of monitoring.

To calculate the sediment volumes supplied by slow mass movement on vegetated banks, we used the process rate value of $2 \mathrm{~mm} \mathrm{yr}^{-1}$ which is based on long-term monitoring assessment of the creep rates using the Young method (Young, 1960; Azhigirov and Golosov, 1990) during previous studies at the same area (Kuznetsova et al., 2012). Soil depth was determined to be approximately $0.7 \mathrm{~m}$ was used for the sediment delivery calculations. 
The total volume of eroded bank material was calculated for the studied river reach for the entire period of monitoring and for a single extreme hydrological event (Table 3).

Total volumes of displaced and mobilized material for the whole $2.3 \mathrm{~km}$ long river reach from all types of the banks range from $150 \mathrm{~m}^{3}$ in the relatively low-water year of 2017 to more than $300 \mathrm{~m}^{3}$ in 2018 when extreme hydrological events occurred during the year of observation. The contribution of one of such events to the total redistribution of coarse and fine sediments along the river may be equal to the annual bank retreat. These preliminary estimates, provide useful information on the contribution of within-channel sources in the total sediment load of the Tsanyk River.

\section{Conclusions}

Monitoring of channel bank retreat using the erosion pin method shows the high general intensity of erosion and associated processes at the wet subtropics. The sediment erosion rates were highly variable depending on local morphology, hydro-climatological and weathering conditions within banks of differing lithology. The main drivers of bank erosion are lithology and its microscale variations, weathering, slope morphology, and bank orientation towards the flow direction. The contribution of these factors may vary substantially, and they all may play the main role in channel bank dynamics depending on local conditions. In general, banks composed of loose alluvial sediments are eroded faster than bedrocks, though in some cases the rates of banks collapses and volumes of mobilized coarse and fine sediments may be comparable. For the latter cases weathering especially active under conditions of wet subtropical climate becomes the leading process.

Volumes of the mobilized material (and the resulting stream sediment load) are highly dependent on the local meteorological and hydrological situation. We suggest that antecedent conditions of the relatively prolonged dry period prior to the most significant hydrological events are the most favorable conditions for extreme channel banks retreat or collapse. Results of the study have practical applications for engineering projects within the valley, evaluation of bank erosion-imposed hazards for different structures along the Tsanyk river channel, as well as for similar small valleys typical for the entire Caucasian Black Sea coast.

Data availability. Pins measurements dataset is available at public data repository. Please, use the link https://zenodo.org/record/3332732\#.XSc8xfZuI0Q (last access: 11 July 2019). For more informantion contact Yulia Kuznetsova (kuzyulia@gmail.com).
Author contributions. YK, VG and NI conceived and designed the research, YK and AT analyzed the data, YK, VG and AT edited the manuscript.

Competing interests. The authors declare that they have no conflict of interest.

Special issue statement. This article is part of the special issue "Land use and climate change impacts on erosion and sediment transport". It is a result of the ICCE Symposium 2018 - Climate Change Impacts on Sediment Dynamics: Measurement, Modelling and Management, Moscow, Russia, 27-31 August 2018.

Acknowledgements. This article was prepared with financial support from the Russian Fund of Basic Researches, project no.1605-00815. The authors wish to thank Dmitry Botavin for the valuable help during fieldwork.

Financial support. This research has been supported by the Russian Fund of Basic Researches (grant no. 16-05-00815).

\section{References}

Alekseevsky, N. N., Magritsky, D. V., Koltermann, P. K., Toropov, P. A., Shkolny, D. I., and Belyakova, P. A.: Floods at the Black Sea coast, Krasnodar region, J. Water Resour., 43, 3-17, https://doi.org/10.7868/S032105961601003X, 2016.

Azhigirov, A. A. and Golosov, V. N.: Estimation of slow mass movement for civil engineering investigations, J. Geomorphologiya, 1, 33-40, 1990.

Gariano, S. L. and Guzetti, F.: Landslides in a changing climate, Earth-Sci. Rev., 162, 227-252, https://doi.org/10.1016/j.earscirev.2016.08.011, 2016.

Golosov, V. N., Delia Seta, M., Azhigirov, A. A., Kuznetsova, Y. S., Del Monte, M., Fredi, P., Lupia Palmieri, E., and Grigorieva, T. M.: Anthropogenic activity influence on exogenic processes intensity in low mountains of the subtropical zone, J. Geomorphologiya, 2, 7-17, https://doi.org/10.15356/0435-4281-2012-27-17, 2012.

Goudie, A. S.: Global warming and fluvial geomorphology, Geomorphology, 79, 384-394, https://doi.org/10.1016/j.geomorph.2006.06.023, 2006.

Hooke, J. M.: An analysis of the processes of river bank erosion, J. Hydrol., 42, 39-62, https://doi.org/10.1016/00221694(79)90005-2, 1979.

Magritsky, D. V.: Spatial and temporal characteristics of the floods at the Black Sea coast of Russian Federation, J. Vestnik of Moscow University, 5, Geography, 39-47, 2014.

Kuznetsova, Y. S., Grigoreva, T. M., Golosov, V. N., Markelov, M. V., Derkach, A. A., and Bolysov, S. I.: Monitoring of exogenic geomorphic processes in urban areas of the Sochi Region, the Caucasian Black Sea coast, in: Antropopresja w wybranych sirefach morfoklimatycznych - zapis zmian w rzezbie I osadkach, Sosnowec, Polonia, 226-230, 2012. 
Lawler, D. M.: The measurement of river bank erosion and lateral channel change: A review, Earth Surf. Proc. Land., 18, 777-821, https://doi.org/10.1002/esp.3290180905, 1993.

Meredith, E. P., Semenov, V. A., Maraun, D., Park, W., and Chernokulsky, A. V.: Crucial role of Black Sea warming in amplifying the 2012 Krymsk precipitation extreme, J. Nat. Geosci., 8, 615619, https://doi.org/10.1038/NGEO2483, 2015.

Neller, R. J.: A comparison of channel erosion in small urban and rural catchments, Armidale, New South Wales, J. Earth Proc. Land., 13, 1-7, https://doi.org/10.1002/esp.3290130102, 1988.

Rodda, H. J. E. and Little, M. A.: Understanding Mathematical and Statistical Techniques in Hydrology, John Wiley \& Sons, Ltd, Chichester, UK, https://doi.org/10.1002/9781119077985, 2015.

Shoygu, S. K. (Ed.): Atlas of natural and anthropogenic hazards and risks of emergency situations of the Russian Federation. Southern federal district, DIK, Moscow, Russia, 2010.
Sirvent, J., Desir, G., Gutierrez, M., Sancjo C., and Benito, G.: Erosion rates in badland areas recorded by collectors, erosion pins and profilometer techniques (Ebro Basin, NE-Spain), J. Geomorphology, 18, 61-75, https://doi.org/10.1016/S0169555X(96)00023-2, 1997.

Thorne, C. R.: Processes and mechanisms of river bank erosion, in: Gravel-Bed Rivers, edited by: Hey, R. D., Bathurst, J. C., and Thorne, C. R., Wiley, Chichester, 227-259, 1982.

Young, A.: Soil movement by denudational processes on slopes, J. Nature, 188, 120-122, 1960. 